UCRL-ID-129847

\title{
Preliminary Description of Small Block Mineralogical Features, Data Report
}

\author{
W. Glassley \\ S. Boyd
}

Febuary 3, 1998

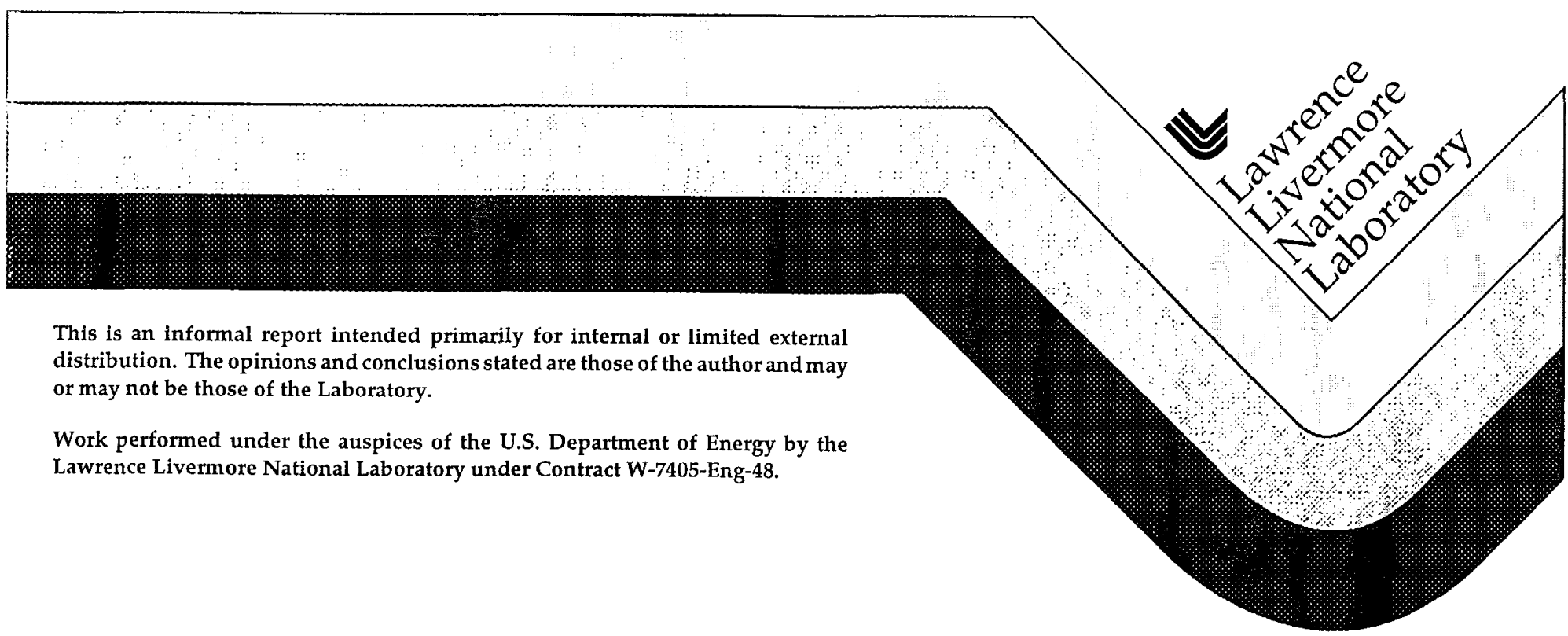




\section{DISCLAIMER}

This document was prepared as an account of work sponsored by an agency of the United States Government. Neither the United States Government nor the University of California nor any of their employees, makes any warranty, express or implied, or assumes any legal liability or responsibility for the accuracy, completeness, or usefulness of any information, apparatus, product, or process disclosed, or represents that its use would not infringe privately owned rights. Reference herein to any specific commercial product, process, or service by trade name, trademark, manufacturer, or otherwise, does not necessarily constitute or imply its endorsement, recommendation, or favoring by the United States Government or the University of California. The views and opinions of authors expressed herein do not necessarily state or reflect those of the United States Government or the University of California, and shall not be used for advertising or product endorsement purposes.

This report has been reproduced directly from the best available copy.

Available to DOE and DOE contractors from the Office of Scientific and Technical Information

P.O. Box 62, Oak Ridge, TN 37831

Prices available from (615) 576-8401, FTS 626-8401

Available to the public from the

National Technical Information Service

U.S. Department of Commerce

5285 Port Royal Rd.,

Springfield, VA 22161 


\title{
Milestone M0L062:
}

\section{Preliminary Description of Small Block Mineralogical Features, Data Report}

\author{
William Glassley and Sierra Boyd
}

\section{Introduction}

The large block heater test, to be conducted at Fran Ridge (Lin et al., 1994), is designed to provide a database with which to test codes that simulate hydrological, geochemical, and geomechanical processes that may occur within the repository block. The geochemical processes that may occur include rock-water interaction within the matrix of fracture bounded blocks, and with the minerals that line fractures (see, for example, Buscheck and Nitao, 1992, 1993a,b, 1994; Glassley, 1993). As a first step in evaluating these interactions, characterization of the fractures, and of the matrix that is adjacent to those fractures, must be completed. Characterization of the fractures and matrix before the large block test is started will allow a "baseline" set of data to be collected that will describe the properties of the large block prior to the test. After the test is completed, the block will be dismembered, and characterization of the matrix and fractures will be repeated. Changes in matrix and fracture mineralogies will allow documentation of the mineralogical consequences of rock-water interaction resulting from heating of tuff under the conditions of the test.

The pre-test characterization of mineralogical properties will be conducted on samples ("small blocks") collected during excavation of the block. The post-test samples will be obtained from the block itself. The latter samples will be obtained from specific temperature and hydrothermal zones, identified through techniques described in the study plan for the large block test (Scientific Investigation Plan, 1993; Lin, 1993). This data report describes the results of small block characterization completed to date.

\section{Qualitative Description of the Small Blocks}

The small blocks were collected during the excavation of the large block test located at Fran Ridge, Yucca Mountain. The rock is near-surface, devitrified, welded Topopah Spring Member of the Paintbrush tuff, predominantly composed of tridymite, quartz, cristobalite, and alkali feldspars (Bish, et al., 1984; Knauss, 1984; Schuraytz, et 
al., 1986; Broxton et al., 1987). The blocks exhibit complex fracture networks with associated alteration. Fracture orientations are usually either subhorizontal or steeply inclined, with notable differences in nature and thickness of fracture fillings.

Textural and color differences in the tuff delimit regions of contrasting alteration (Figure 1). In the least altered portions of fracture-bound blocks, lithic fragments within the devitrified and welded tuffs are clearly evident as dark, chocolate brown areas, millimeters to a few centimeters in cross section, set in a lighter, orange-brown matrix. Alteration around fractures tends to color the rock a lighter hue, masking the color contrast between lithic fragments and the enclosing matrix, thus tending to make the rock appear more homogeneous than it really is.

The surfaces of the first set of fractures are coated by a thin sheet of dark material $<.1 \mathrm{~mm}$ thick, which defines the fracture plane. These fractures are surrounded by a thick (2 to $10 \mathrm{~cm}$ ), "bleached" alteration zone, which is responsible for the apparent change in texture described above. It is within this zone that the lithic fragments in the tuff tend to lose their characteristic dark color. In general, the bleached zone is lightest adjacent to the fracture plane, and grades into unaltered tuff without abrupt transitions. No evidence of displacement along these fractures was apparent. These fractures are virtually healed in all instances where they were observed.

Cutting the first fracture set is a later fracture generation (Figure 1). This second set usually dips at a high angle, but the dip is highly variable. Strike of these fractures is grossly N-S, although E-W fractures are also evident that have similar features. These fractures are generally filled with a white material. Fracture filling features vary in thickness from a fraction of a millimeter to more than 10 millimeters. Fracture openings (fracture aperture) vary from vuggy regions a centimeter across, to regions that are completely healed. The rock at the edge of these fractures is often a dark brown or maroon color, for a distance of $.1 \mathrm{~mm}$ to $5 \mathrm{~mm}$ away from the fracture edge. Often these fractures occur in pairs that suggest a conjugate relationship. Movement along these fractures is recorded by offset of lithic fragments and crosscutting fractures, with displacements of up to $2 \mathrm{~cm}$. The sense of offsets was consistently that expected for high angle normal faulting, with a significant component of oblique slip. Alteration around these fractures is often less prominent than that around the first fracture set, although some bleaching occurs in some cases.

When sawn surfaces are wetted and left in the sun, the pattern of drying suggests that several porosity domains occur, which correlate with the color domains. One domain, the tan-orange homogeneous bleached zones adjacent to the subhorizontal fracture set, dries very quickly. The region in which lithic fragments are clearly apparent dries more 
slowly, resulting in a mottled appearance due to the local variability in porosity associated with the clasts. The clasts themselves, and the second fracture set, dry the most slowly. If these observations relate to porosity, they suggest that alteration around the subhorizontal fractures has significantly reduced and homogenized the bulk porosity, while the interiors of fracture-bound blocks have relatively high and variable porosities.

Infiltration studies were conducted in the field on cut blocks approximately 1 meter on a side. Water was poured into open fractures at a rate that approximately kept the fracture filled at the inlet point. The time and location of water appearing on fractures on the vertical faces was noted. In four cases, water appeared in fractures on the vertical face at approximately the same distance away from the block edge as was the inlet point. In other words, dispersion would have to be sufficient to result in a flow path inclined approximately forty-five degrees from the top, horizontal surface where the inlet point was located. An unexpected feature was the prominent development of flow pathways along fractures too small to observe with the naked eye. In this case water flowed down a fracture having an aperture of .5 to $1 \mathrm{~cm}$ for a distance of approximately fifteen $\mathrm{cm}$ and then diverted along a micro-crack. At this point, flow became spasmodic; the water would move about 1-2 mm along the micro-crack, then stop while water was imbibed into the adjacent matrix. After roughly 10 seconds, and imbibing into the rock 1 to $2 \mathrm{~mm}$, it would then rapidly flow another 1-2 mm along the micro-crack and then stop, and repeat the process. Once the flow continued, no further imbibition took place. Hence, the wetted region around the micro-crack remained the same thickness. As this process continued, 5-12 cm away from the tip of the micro-crack, another line of water appeared that exhibited the same behavior, and for which no macroscopically visible crack could be seen. Eventually, the flow along these micro-cracks converged, demonstrating that these features were part of one continuous micro-crack that extended for a distance of at least $25 \mathrm{~cm}$. When we returned to view the block several days later, all of the cracks had dried, but there was evident a white discoloration where the wetting and imbibition had occurred along the micro-cracks, suggesting that salts had been mobilized and deposited by the flowing water. There was insufficient material to collect for analysis, however.

\section{Analytical Methods}

\section{Microscope}

Polished thin sections were examined using the Nikon Optiphot 2-Pol polarizing microscope to characterize textural relationships and mineralogy in the various regions 
observed in the field. Polaroid photographs were taken of representative transects crossing the fractures (Figures 3-5).

X-ray Diffraction

Scrapings and chips were collected from different zones of interest on the small blocks. These included representative samples from the unaltered matrix, from the dark maroon regions bounding the second generation of fractures, and from the bleached regions associated with the first generation fracture set. For powder diffraction (XRD) studies, the collected samples were first crushed to ca. $5 \mathrm{~mm}$ granules using a washed, steel crusher, and then ground to 10-20 micron powder using a micro-mill. A Scintag Xray diffractometer, using $\mathrm{Cu}$ anode sealed tubes to generate $\mathrm{X}$-rays at $45 \mathrm{kV}$ and a current of $35 \mathrm{~mA}$, was used to collect the spectra from $2-62^{\circ} 2 \varnothing$, using $0.02^{\circ}$ steps and counting times of 1.0 second per step.

Electron Microprobe Analysis

Electron microprobe examination of fracture alteration was undertaken to refine the phase identifications from the XRD. A four spectrometer JEOL Super Probe with EDS and Tracor Northern software was used. An accelerating voltage of $15 \mathrm{kV}$, and a current of 25 nanoamps was used.

\section{Results}

The unaltered matrix material is composed of albite, quartz, cristobalite, potassium feldspar, and very fine grained hematite(?). Minor amounts of calcite are found locally. Phenocrysts of sanidine, plagioclase, and quartz, and altered biotite, are occasionally present. Lithic fragments are composed of pumice fragments, flattened to varying degrees during welding, and felsic volcanic lavas. Alteration textures are ubiquitous, and highly varied, and include spherultic textures, remnant vitric textures, and fine grained granophyric alteration. In all respects, these samples are texturally identical to those described by Knauss (1984) from Busted Butte, who presented numerous photomicrographs and SEM images of the observed textural relationships in TSw2 from that locality.

The mineralogy of the first generation fracture fillings consists of a silica polymorph (cristobalite?) with an iron or manganese oxide. No carbonates were observed. A very fine grained, green sheet silicate (chlorite?) rarely occurs, and is associated with the opaque phase. Over a distance of about 1 to $2 \mathrm{~mm}$ the fractures are 
bounded by a fine grained area that is primarily a silica polymorph that appears to be cristobalite. Within this region the original textures of the welded tuff are replaced by a felted texture, although vague relicts of the original texture can be seen in places. This region composes the most central portion of the bleached zones. Further away from the fractures, the bleached zones have the same principal mineralogy as the matrix, with the exception of variation in the relative abundances of cristobalite and quartz. Between the unaltered matrix material and the centers of the bleached zones, quartz and alkali feldspar systematically as cristobalite becomes the dominant silica polymorph (Figure 2). This change directly correlates with the change in color of the bleached zones, the lighter regions mapping the areas of greatest cristobalite concentration.

The second generation fractures are filled by calcite, quartz, potassium feldspar, and a barium-rich phase or phases tentatively identified as barite and hollandite. The association of barium with sulfur in X-ray maps generated with the electron microprobe suggests that the former identification is most likely. Hollandite and barite, however, have both been reported in veins from drill core (Carlos et al., 1990, 1993), and both may thus be present in these Fran Ridge samples. Further work is underway to positively identify the barium-bearing phases. The alteration around the fracture fillings is complex (Figures 3-5). Immediately adjacent to the fracture filling is a region that is not always present, and which remains problematic. It is nearly opaque (Figures 3,4 ), and is exceedingly fine grained. $\mathrm{X}$-ray maps have not indicated that it is significantly different in composition from the remaining matrix material. Further work is underway to identify the mineralogy and significance of this material. Further away from the fracture filling there usually occurs a zone of alkali feldspar and silica polymorphs intimately intergrown in spherultic textures. The original textures of the tuff are present only as ghost-like remnants defined by variation in abundance of fine grained oxides. Scattered throughout this zone are small fluid inclusions, many of them decrepitated. Toward the outer edge darker fine grained mineral phases become more prominent, the original textures are more evident, and the oxide phases become more abundant. At the outer edge of the alteration zone (Figure 5) there is a sharp transition into the original textures of the devitrified and welded tuff. Most striking is the presence of very fine hematite (?) needles in the unaltered tuff, and its replacement by nearly opaque, fine grained material.

\section{Discussion}

The first generation fracture set may have a strong impact on matrix properties. The variations in cristobalite and quartz abundance associated with the first generation 
fracture set suggests that development of those fractures was associated with a recrystallization event that affected silica distribution in the rock. Although quantitative whole rock analyses have yet to be made, the dramatic increase in cristobalite peak heights, and relatively small decreases in orthoclase and quartz peak heights in the XRD patterns, and the textural changes seen in thin section, imply that silica-rich fluids infiltrated the rock from the fractures. The relatively large distances affected suggest that these fluids may have persisted for quite some time and/or were relatively hot. The drying behavior described under qualitative observations suggest that this alteration process may have reduced the bulk porosity and/or permeability in regions in which this recrystallization was most extensive. Visual estimates of the areas affected by the color changes suggest that up to $50 \%$ of the volume of fracture-bound blocks may have experienced this alteration.

The second fracture generation represents that portion of the rock that will control fracture flow, since these are the fractures that have void space that will allow fluid movement. The mineralogy of these fractures is complex, and will result in important, but as yet unquantified, changes in water chemistry, as fluids interact with fracture filling minerals. Our observations of the second generation fracture set mineralogy are consistent with the descriptions of fracture mineralogy described by Carlos et al.(1990, 1993), particularly in the occurrence of Ba-bearing mineral phases. Although barite is sparingly soluble (Holland and Malinin, 1979), movement of water from matrix to fractures must result in chemical reactions since the matrix mineralogy is dominated by silicates while the fracture mineralogy is dominated by carbonates and sulfates. The effect of the resulting reactions on fracture aperture has yet to be established.

Imbibition of water along fractures during fluid flow may be highly variable, since the second generation fracture set intersects the bleached zones at high angles, and it is the bleached zones that may mark important regions of porosity reduction associated with cristobalite formation. Characteristic curves for the unaltered matrix and the bleached zones will be required, in order to fully characterize the hydrological properties of the tuff matrix.

\section{Conclusions}

Two distinct fracture sets can be recognized in small blocks collected during excavation of the large block. The fractures in this first generation are subhorizontal, and completely sealed. They are very thin $(<.1 \mathrm{~mm})$, and consistently have a bleached zone 2$10 \mathrm{~cm}$ wide around them. This bleached region is associated with significant increase in 
cristobalite abundance in the rock, and with apparent silica enrichments, and porosity reduction. The second set of fractures tends to be steeply dipping. These fractures are much wider, occasionally possessing vuggy regions up to a centimeter wide, and have open channel ways. The fractures are partially filled with calcite, potassium feldspar, quartz and at least one barium-bearing phase that is associated with sulfur (probably barite).

These characteristics have important implications for hydrological characteristics of the rock, and for geochemical modeling. Further work will focus on refining the mineralogical identifications and mineral distributions, and ascertaining the implications of the mineralogical variations on the geochemical evolution of the blocks during heating.

\section{Acknowledgements}

The authors thank S. Roberts for XRD and electron microprobe analyses. Prepared by Yucca Mountain Site Characterization Project (YMP) participants as part of the Civilian Radioactive Waste Management Program. The YMP is managed by the Yucca Mountain Site Characterization Project Office of the U.S. DOE, Las Vegas, Nevada.

\section{References}

Bish, D.L., A.E. Ogard, D.T. Vaniman, and L. Benson (1984), Mineralogy-Petrology and Groundwater Geochemistry of Yucca Mountain Tuffs, Mat. Res. Soc. Symp. Proc., Vol. 26, pp. 283-291.

Broxton, D.E., D.L. Bish, and R.G. Warren (1987), Distribution and Chemistry of Diagenetic Minerals at Yucca Mountain, Nye County, Nevada. Clays and Clay Minerals, 35, 89-110.

Buscheck, T. A., and J. J. Nitao (1992), The Impact of Thermal Loading on Repository Performance at Yucca Mountain, in Third International Conference on High Level Radioactive Waste Management, Las Vegas, American Nuclear Society, LaGrange Park, I1l., 1003-1017.

Buscheck, T. A., and J. J. Nitao (1993a), The Impact of Repository-Heat-Driven Hydrothermal Flow at Yucca Mountain, Lawrence Livermore National Laboratory, Livermore, Calif., UCRL-JC-112444. 
Buscheck, T. A., and J. J. Nitao (1993b), The Impact of Repository Heat on ThermoHydrological Performance at Yucca Mountain, Lawrence Livermore National Laboratory, Livermore, Calif., UCRL-JC-114791.

Buscheck, T. A., and J. J. Nitao (1994), The Impact of Repository Heat on Hydrological Behavior at Yucca Mountain, Lawrence Livermore National Laboratory, Livermore, Calif., UCRL-JC-115798.

Carlos, B.A., S.J. Chipera, D.L. Bish, and S.J. Craven (1993), Fracture-Lining Manganese Oxide Minerals in Silicic Tuff, Yucca Mountain, Nevada, U.S.A., Chemical Geology, 107, Elsevier Science Publishers B.V., Amsterdam, pp. 47-69.

Carlos, B.A., D.L. Bish, and S.J. Chipera (1990), Manganese-Oxide Minerals in Fractures of the Crater Flat Tuff in Drill Core USW G-4, Yucca Mountain, Nevada, Los Alamos National Laboratory, Los Alamos, New Mexico, LA-11787-MS.

Glassley, W. E. (1993), Coupled Hydro-Geochemical Processes and Their Significance for Yucca Mountain Site Characterization, in Proceedings of the ANS Topical Mtg. on Nuclear Waste Isolation in an Unsaturated Zone, Focus ' 93 (American Nuclear Society, La Grange Park, IL), p. 122-126.

Holland, H.D., and S.D. Malinin (1979), The Solubility and Occurrence of Non-Ore Minerals, in H. Barnes (ed.) Geochemistry of Hydrothermal Ore Deposits, J.Wiley and Sons, New York, 461-508.

Knauss, K.G. (1984), Petrological and Geochemical Characterization of the Topopah Spring Member of the Paintbrush Tuff: Outcrop Samples Used in Waste Package Experiments, Lawrence Livermore National Laboratory, Livermore, Calif., UCRL-53558.

Lin, W. (1993), Technical Basis and Programmatic Requirements for Large Block Testing of Coupled Thermal-Mechanical-Hydrological-Chemical Processes, Lawrence Livermore National Laboratory, Livermore, Calif., UCRL-ID-112834.

Lin, W., D.G. Wilder, J.A. Blink, S.C. Blair, T.A. Buscheck, D.A. Chesnut, W.E. Glassley, K. Lee, J.J. Roberts (1994), The Testing of Thermal-Mechanical-HydrologicalChemical Processes Using a Large Block, Lawrence Livermore National Laboratory, Livermore, Calif., UCRL-JC-114776. 
Roberts, S. (1995), X-ray Analyses of Yucca Mountain Rock Samples, memo to Sierra Boyd.

Schuraytz, B.C., T.Z. Vogel, and L.W. Younker (1986), Geochemical Gradients in the Topopah Spring Member of the Paintbrush Tuff: Evidence for Eruption Across a Magmatic Interface, Lawrence Livermore National Laboratory, Livermore, Calif., UCRL-53698.

Scientific Investigation Plan (1993) for Yucca Mountain Project WBS 1.2.2.2.4, Large Block Testing of Coupled Thermal-Mechanical-Hydrological-Chemical Processes. Lawrence Livermore National Laboratory, Livermore, Calif., SIP NF-02, 56 pp. 


\section{Figure Captions}

Figure 1: Sawn surface of small block from sample SPC00504577, showing first and second fracture generations. The long axis of the figure is vertical, and $40 \mathrm{~cm}$ long. Note the bleaching associated with the first fracture generation, and its subhorizontal aspect. The unaltered matrix is that region in which brown lithic fragments are prominently seen. The second fracture generation is indicated, and the white fracture filling mineralogy is evident. Open void spaces along this fracture can be seen as black, irregular forms along the fracture.

Figure 2: XRD patterns of samples taken in unaltered matrix material (A. Unaltered matrix), $5 \mathrm{~cm}$ from center of bleached zone (B. Intermediate bleached zone), and in the center of the bleached zone ( $C$. Central bleached zone). Note the increase in the cristobalite peak, and decrease in quartz and alkali feldspar peaks, when going from the unaltered matrix to the center of the bleached zone. Note vertical scale differences.

Figure 3: Photomicrographic mosaic of second generation fracture, and the alteration zone associated with it. Long axis of figure is $1.5 \mathrm{~cm}$ long.

Figure 4: Photomicrograph of region immediately adjacent to second generation fracture filling. Long dimension of figure is $15 \mathrm{~mm}$. The opaque rim marks the edge of the fracture. Remnant vitric textures can be seen in the altered rock.

Figure 5: Photomicrograph of the boundary between the altered zone around a second generation fracture, and the unaltered matrix. The small needles in the prealteration matrix are hematite (?). They are absent in the altered material, and are replaced by larger opaque clots of an unknown phase. Long dimension of the photomicrograph is $1 \mathrm{~mm}$. 


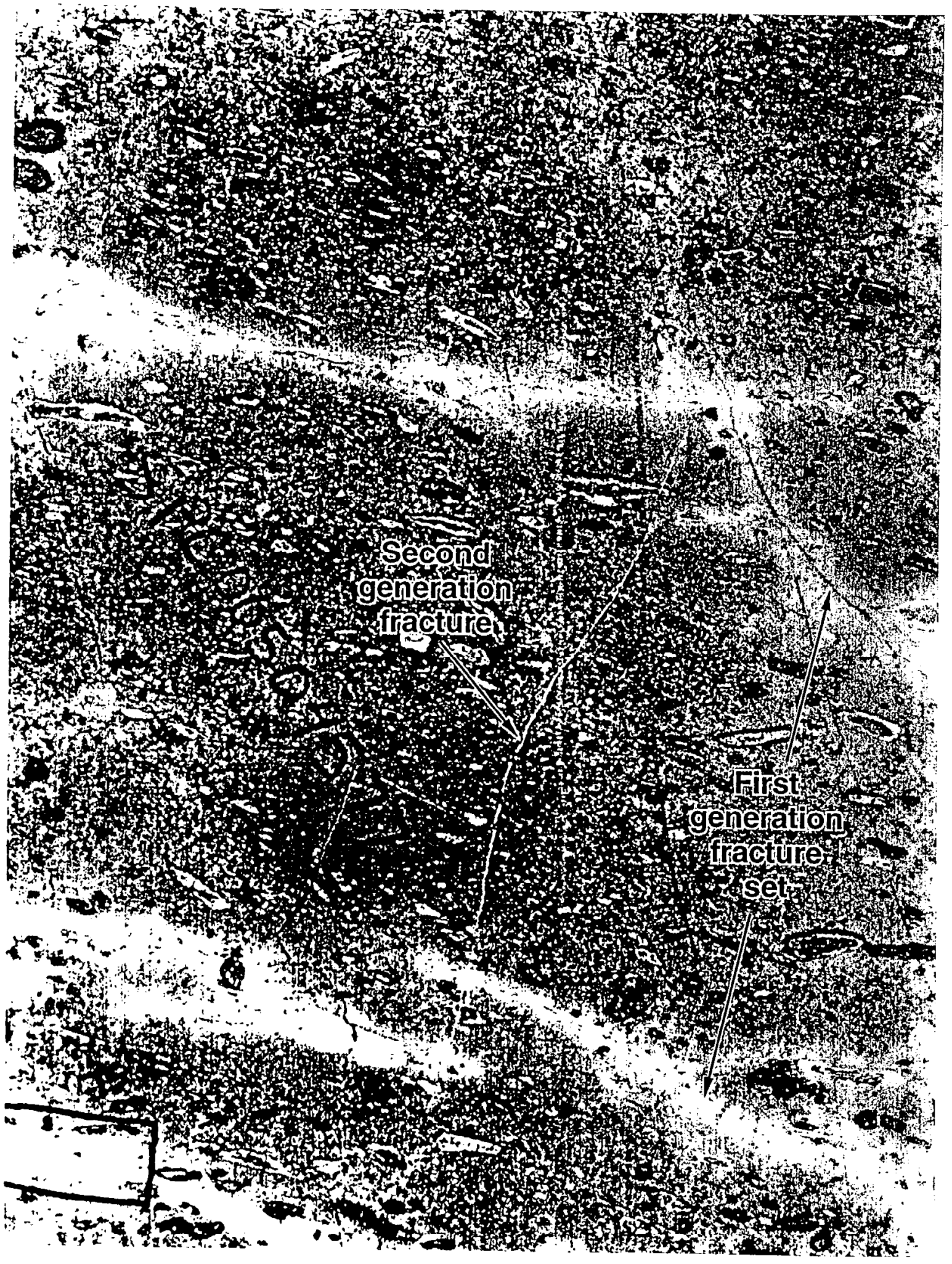

Figure 1 


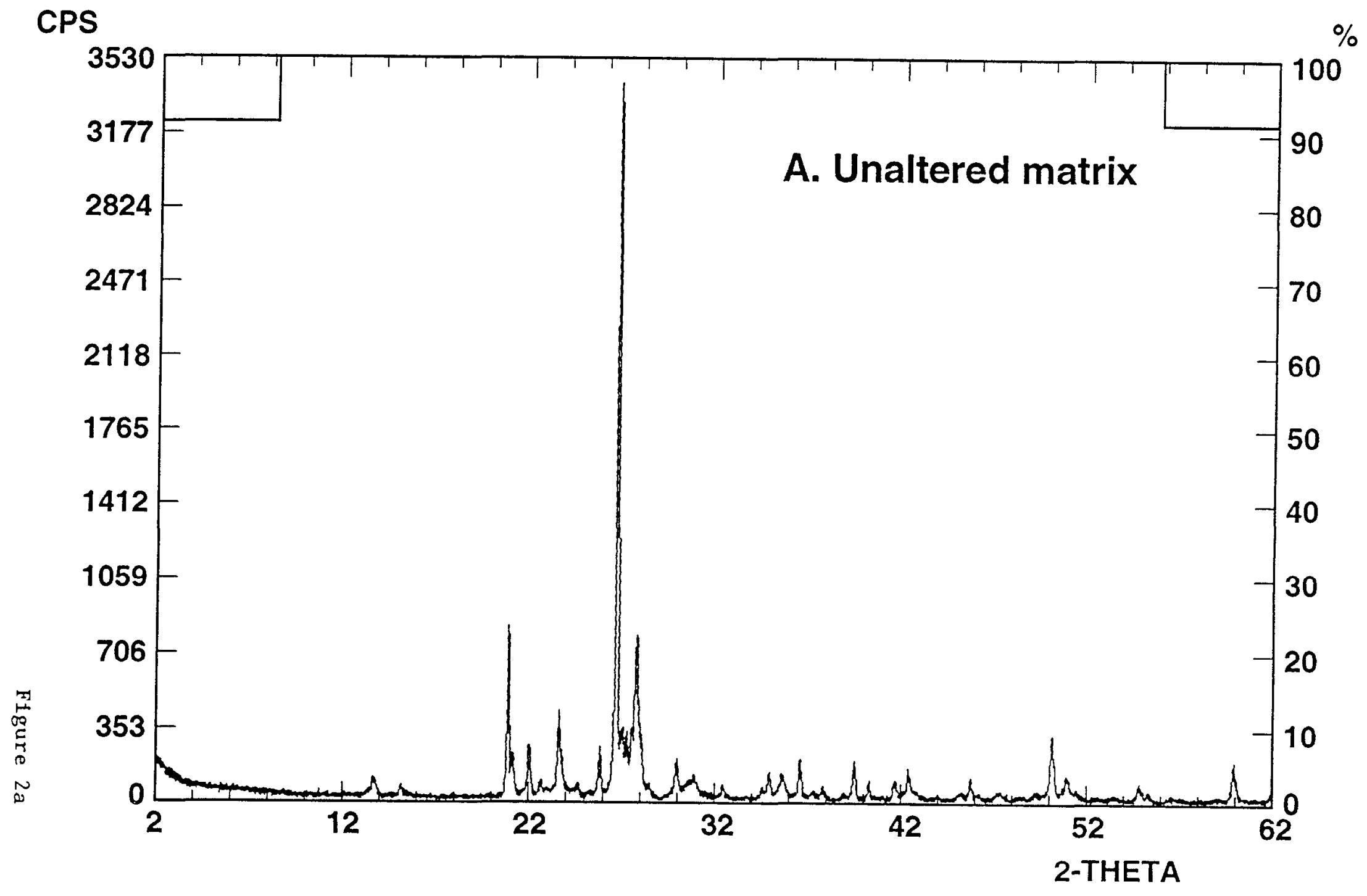




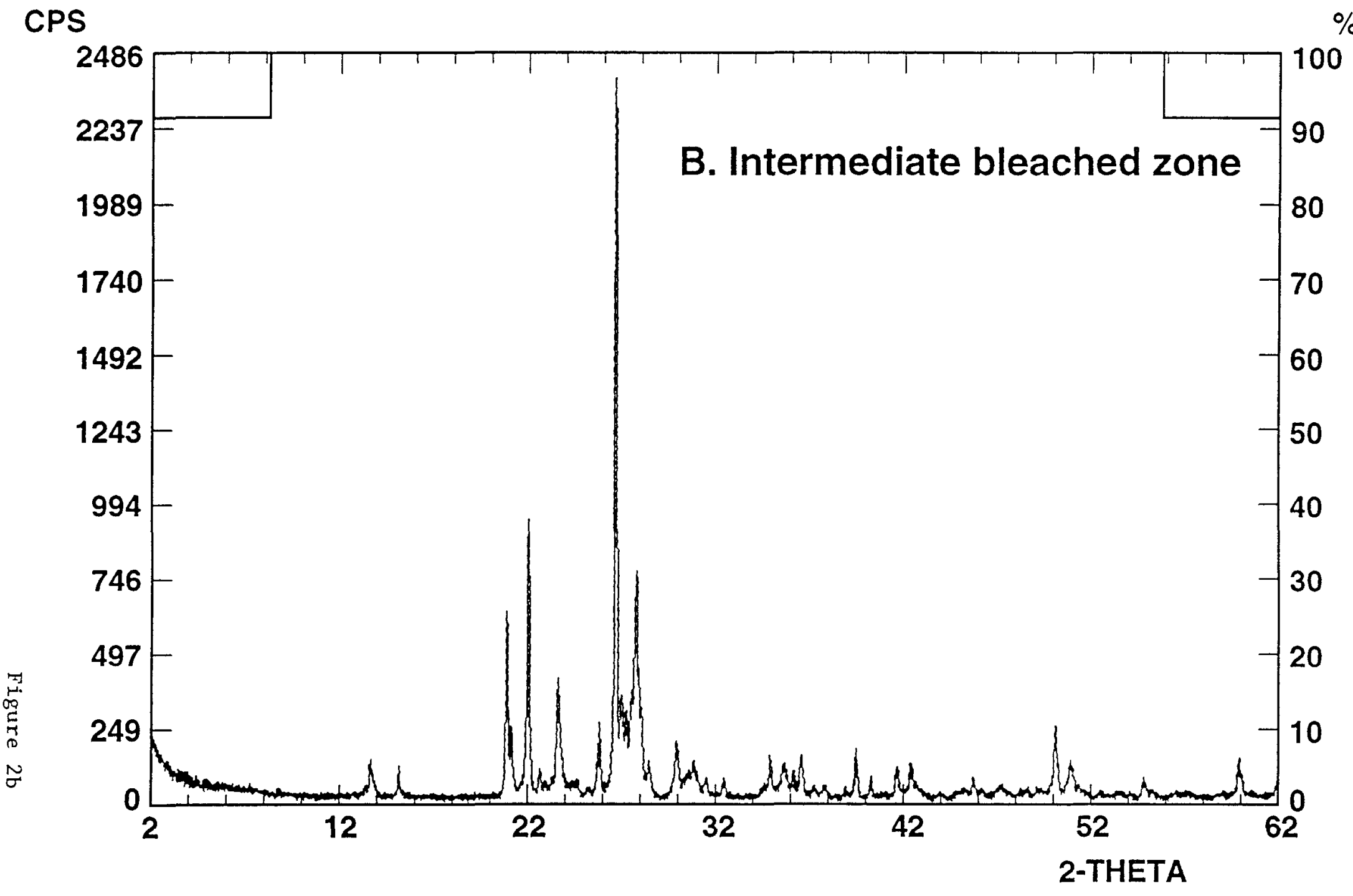




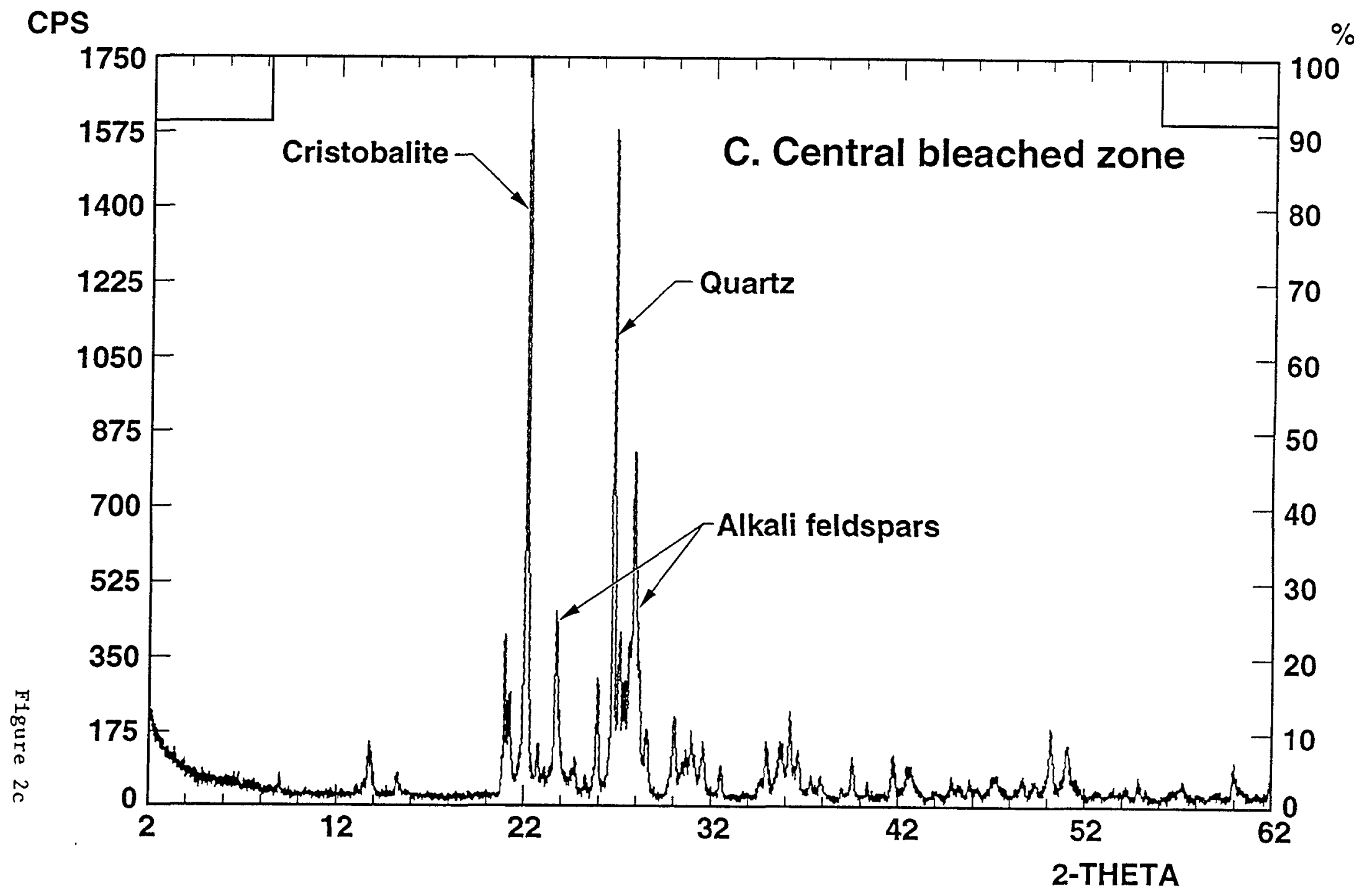




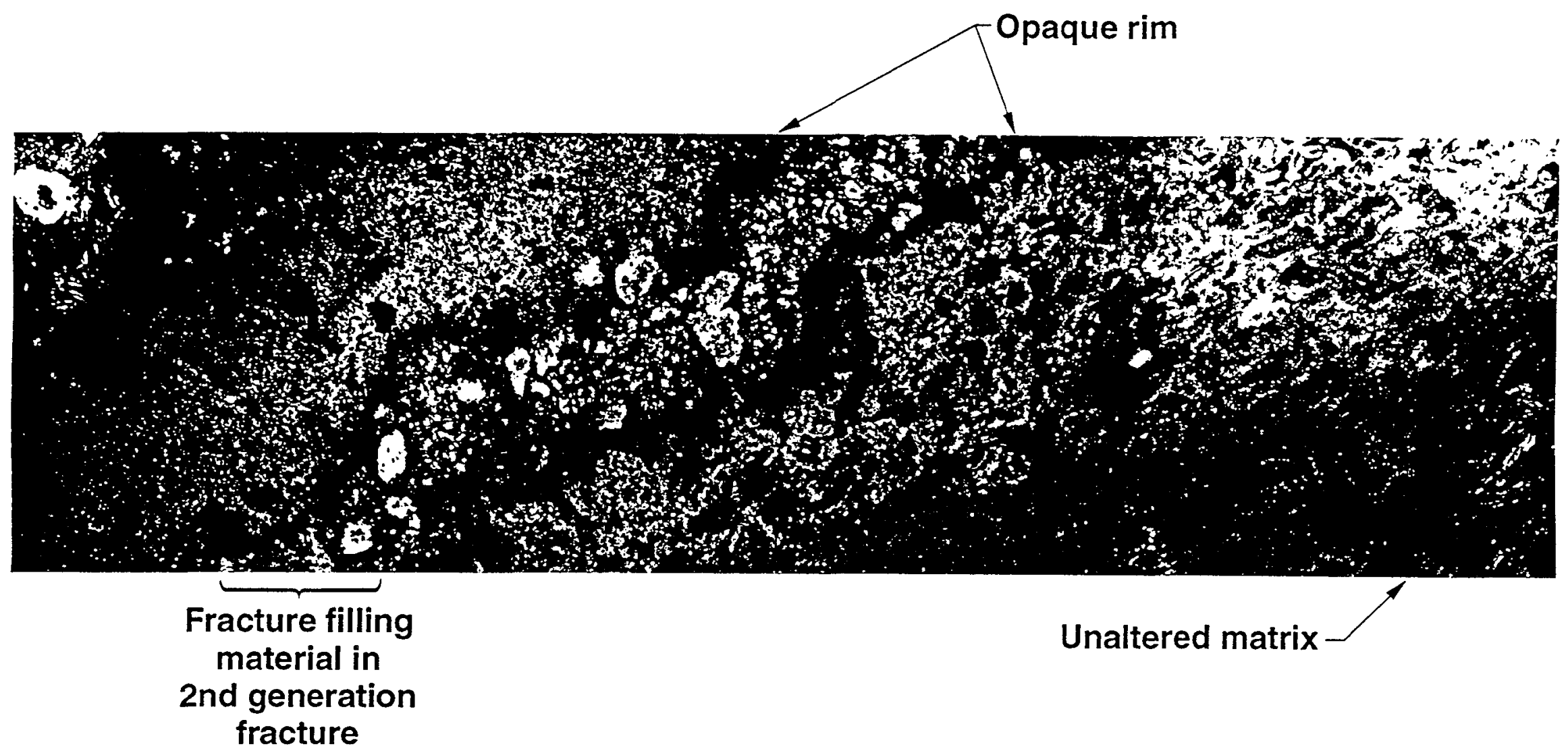




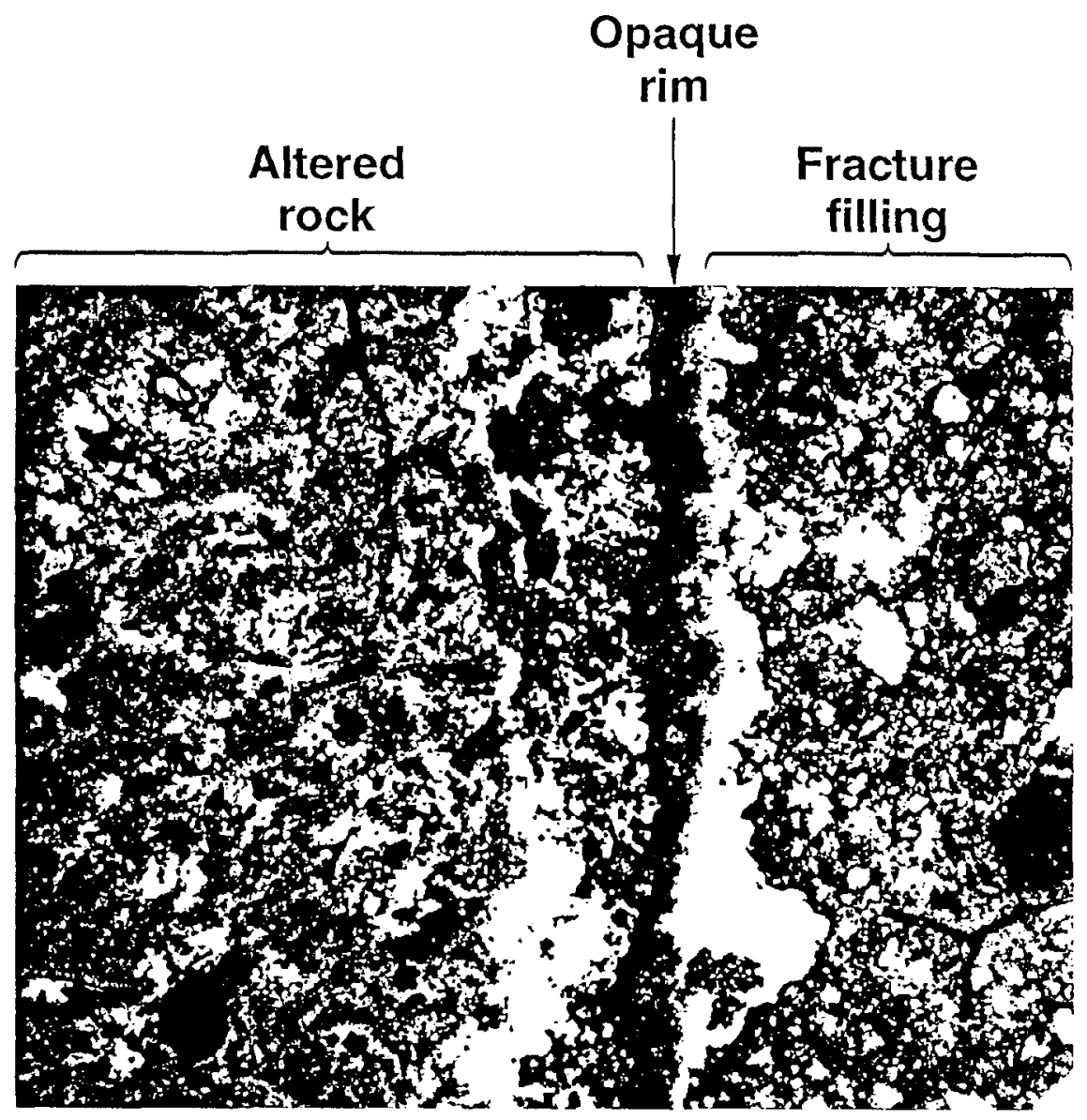




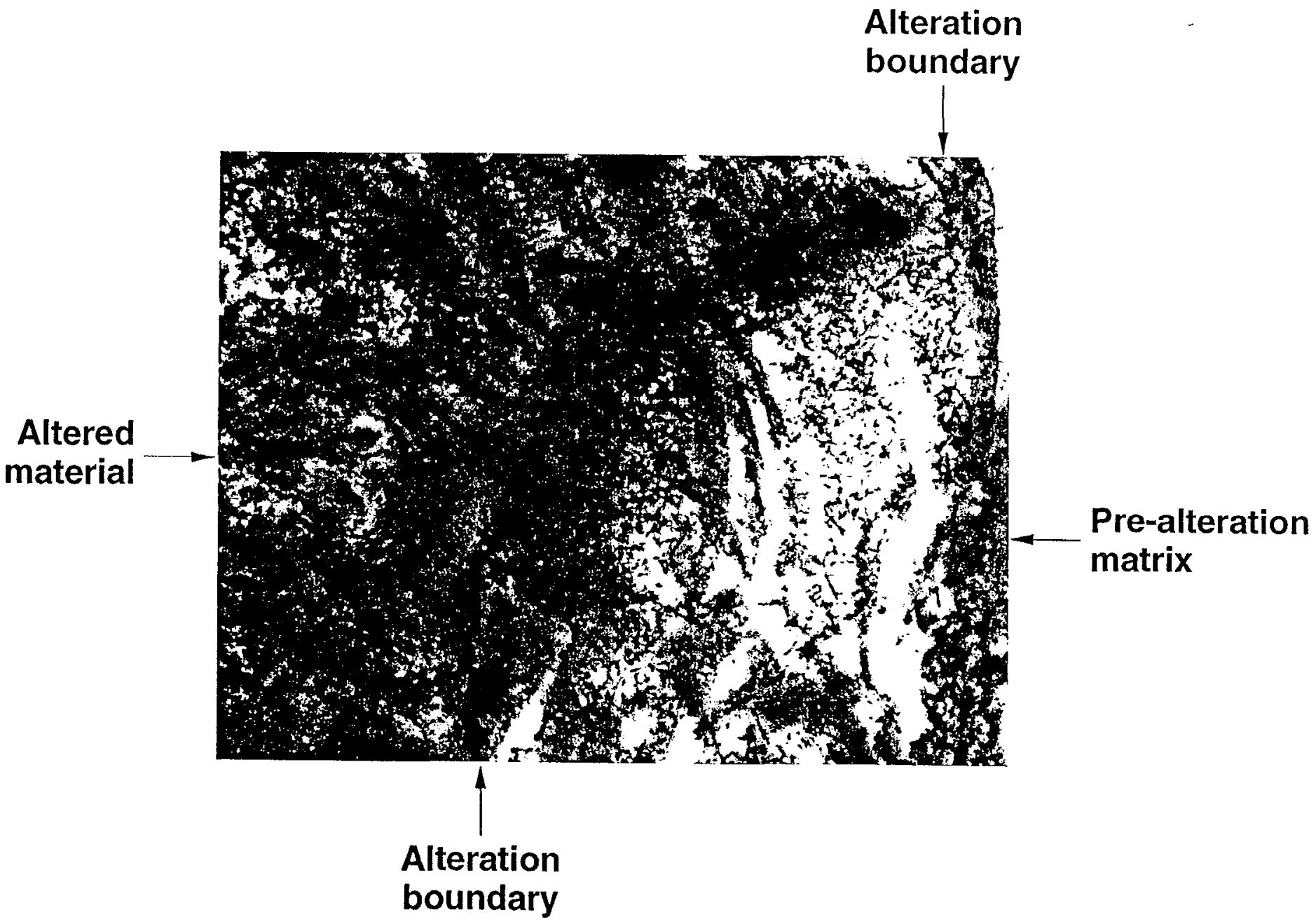




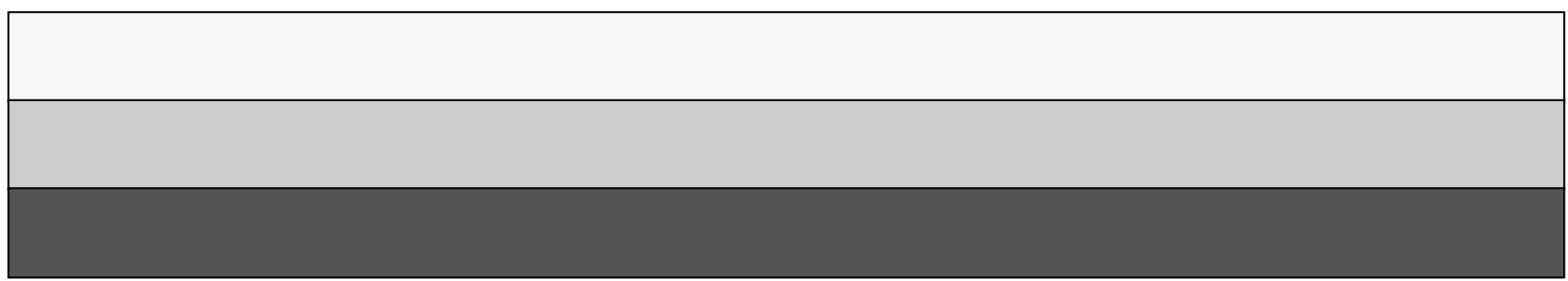

